\title{
AN ANALYSIS OF THE THIRD SEMESTER STUDENTS' ABILITY IN DEVELOPING NARRATIVE TEXT OF ENGLISH EDUCATION STUDY PROGRAM IN MUHAMMADIYAH UNIVERSITY OF METRO
}

\author{
Aulia Hanifah Qomar \\ English Department of FKIP Muhammadi yah Uni versity of Metro Lampung \\ aulya_moetz@yahoo.com
}

\begin{abstract}
:
An Analysis of The Third Semester Students' Ability in Developing Narrative Text of English Education Study Program in Muhammadiyah University of Metro.Applied Linguistics Departement. English Education Study Program, Faculty of Education and Teacher Train ing in Muhammadiyah University of Metro.An analys is of The Third Semester Students' Ability in Developing Narrative Text of English Education Study Program in Muhammadiyah University of Metro is the point because, the students worse in writing. They have many problems, actually writing genre and especially in narrative text. The purpose from this research is to analyze students' ability in developing narrative text, and to know what the problem it happened to the students. The subjects of this research were the third semester of English education study program, and the sum of this subject was 36 students.

This research used qualitative research. The data was collected by using questionnaire. The predicted research finding is the most valuable one that the students' writing ability can be well, if we practice in our daily activity like make a story.
\end{abstract}

Keyword: Ability, Analysis, Narrative text

\section{INTRODUCTION}

Language is the most important for each people as a communication and interaction in society. Most of the students in Indonesia should study English as a foreign language. It can be applied through spoken or written forms. English language has four important skills. There are listening, speaking, reading and writing. In this chance, the researcher will discuss about writing.

There are many processes involve in writing. In general, these can be classified into pre-writing, writing, and revising (Perl, 1980 pp.31, 363-369; Raimes, 1987 pp. 439-468). However, within these broad categories, the art and science of composing and producing a paragraph consist of a series of complex, recursive, and often uniquely individual steps. The students are able to make a narrative text based on their own word. It means that the students are expected to be able to use English based on the genres in their writing.

The students have many problems when they learn English. Beside of the students less in learn English especially in writing. They still confuse to use the tense in narrative text. Not only they use of past tense when they are writing narrative text, but also they use of present tense. The lecturer should give explanation about formula of past tense before the lecturer asks the students to make a narrative text.

In fact, the students' writing ability in developing narrative text is still far from the objectives. Most of the students get many problems when they write their text. 
The students are less use vocabulary in writing so that they have difficulties to express their ideas in developing narrative text. They still do not know about the part of narrative text clearly. Since writing is considered difficulties to be mastered by the students, the lecturer should always look for suitable techniques to be applied to the students, in order to make the students interested in learning writing. In this chance, the researcher wants to analyze about students' writing ability in developing narrative text of the third semester of English Education Study program in Muhammadiyah University of Metro, Academic Year 2014 / 2015. The researcher used qualitative research method to do this research. Based on data presurvey :

Table 1. Students score list at the fourth semesterof English Education Study program in Muhammadiyah University of Metro, Academic Year 2014 / 2015

\begin{tabular}{|l|c|c|c|c|}
\hline No & Score & Category & Sum & Percentage \\
\hline $\mathbf{1 .}$ & $\geq 5.5$ & Pass & 10 & $33 \%$ \\
2. & $\leq 5.4$ & Fail & 20 & $67 \%$ \\
\hline & Total & & $\begin{array}{c}\sum \mathbf{3 0} \\
\text { students }\end{array}$ & $\mathbf{1 0 0 \%}$ \\
\hline
\end{tabular}

Source : Test of narrative text of writing subject of English Education Study Program in Muhammadiyah University of Metro on April $3^{\text {rd }}, 2015$.

Based on the students' pre test, the researcher gets the point that it need to do the problem analyze especially in writing narrative text, because not all yet of the students are passing in this matter. They got score $\leq 5.4,67 \%$. It means that they find some difficulties in writing narrative text.

Looking for some of the students' difficulties in writing developing narrative text, the researcher gets conclusion that the students must have wide knowledge about something, like story and apply it to make paragraph especially in writing narrative text, and the students can get an important moral massage from the text, that can make the students more enjoy in learning English.

Looking the problem background above, the researcher can identify some problems which are discovered as follow:

1.1.1 The students less learn English especially in writing.

1.1.2 The students do not know the tenses which must be used in narrative text.

1.1.3 The students less use vocabulary mastery in writing.

1.1.4 The students have difficulty in developing narrative text.

1.1.5 The students do not know about the part of narrative text clearly.

1.1.6 The students have the difficulty to make the title from the theme.

Based on the problem identification, in this research the researcher only focus on the students' difficulty in developing narrative text and the students' knowledge about the part of narrative text.

Seeing the problem limitation, the formulation of the problem in this research is determined as follows: 
1.2.1 How far the students' writing ability in developing narrative text?

1.2.2 How far the students' competency about the part of narrative text?

Some objectives of this research dealing with the research are drawn as follows:

1. To describe students' writing ability in developing narrative text.

2. To know what the students have studied part of narrative text clearly by analysis.

Based on the research objective above, the researcher can show the research benefit such as :

1. The contribution in learning English for the students and in developing narrative text.

2. As the consideration to be concerned side in the research about narrative text.

\section{REVIEW OF RELATED TO LITERATURE}

As we know that, writing is basically the process of expressing ideas and tho ughts of the writer using knowledge of structure and vocabulary to combine the writer's ideas as a means of communication. Writing refers to a tool connecting between the writer's and the reader's though. Writing and reading were considered separate skills: the writer wrote a massage, and later, the reader extracted the massage (Joy M. Reid, 1994: 1).

Yangrifki (2008: 1) state that narrative scaffold could be used to improve the students writing ability. The teaching and learning process is conducted by using genre based approach that consisted of three stages. Te first stage is building knowledge of the field, in which the students are introduced to the social context and feature of the narrative text by using a model text. The second stage is modeling, and the third stage is joint construction of the text in the research at SMAN 1 Gambiran at XI IPS 1 the writer found that they had difficulty I writing narrative text, particularly in term of the content and organization.

Mayves, M and Pierce, Jennifer (2005) said that attention to where we are situated in trying to understand personal narratives and how we come to understand them alert-readers to the located and partially of our interpretations and knowledge the practical steps taken to account for the conditions through which personal narratives are produced, analysis can make stronger and more credible claims about their interpretative work.

According to the statement above, the researcher find out that the students had difficulty to write narrative text especially to organize their story in a good text and to distinguish the genre from the text, they do not know the characteristic from each text types. So the researcher give more knowledge about the part of narrative, like : social function, generic structure, significant lexical grammatical and the differenced from this research is the students low in vocabulary comprehension and still confused about the tenses in used.

In writing, the writer explains to other something that happened. It has three important qualities; it tells an event, in generally describes events in chronological order, and makes a point. For example, fairy story or personal experiences of a particular incident which happened to person. It will be a case chosen in this research.

The distinction of this paper from their statement that this paper explains about analysis students' ability in developing narrative text, and the researcher just explains or like 
presents about the students' ability without some reflection about the problem happen to the students so that the students' ability low in developing.

The weakness of their statement that we just know the theory from their research we do not know deeply about the problem, so we do not know what the reflection we must do to the problem happen to the student.

Analysis is the most established and esteemed forum in which to publish short discussions of topics in philosophy. Analysis maintains a distinctive, concise style and converse a wide range of topics including. Philosophical logic and political philosophy (Oxford Journa1, 2009: 587-589). Based on the researcher, analysis is doing research about a problem happen in an area, so that there are the explanation deepest and the conclusion from that problem.

A concept analysis is a process of examining written and unwritten sources of information on a concept to clarify its uses and meaning. Several nurse scholars have written and described the process in relation to building theory (MeEwen \& Wills, 2007: p.52; Chinn \& Kramer, 1999: p.174; Rodgers, 1993: p.88-94; Schwartz-Barcott \& Kim, 1993: p.253-277; Walker \& Avant, 2005: p.185-210).

The process is usually done in early theory building efforts or when the literature on the concept is unclear. A concept analysis, as used in this course assignment, is a rigorous process whereby a concept is examined using published written sources. The student conducting the analysis chooses a concept of interest to her/him and progresses through a number of steps in analyzing and synthesizing the literature to arrive at a complete picture of what the concept looks like: its causes, characteristics, and consequences.

Ability is a level of skill or intelligence or quality of being able to do something, especially the physical, mental, financial or legal power to accomplish something (Oxford Advanced Learner's DictionarySixth Edition, 2000:2). The other meaning of ability is possession of the necessary skill or power to do something, great skill or competence, the quality of being able to perform a quality that permits or facilitates achievement or accomplishment. (Kate Chopin, 2003: 12).

In the writing ability there are five aspects of writing. These aspects adopted from H.L. Jacob et.al. : 1981: 90), they are ;

1) Content refers to the substance of writing, the experience of the main idea (unity).

2) Organization refers to the logical organization of the content (coherence).

3) Vocabulary refers to the selection of the words those are suitable with content.

4) Language use refers to the use of the correct grammatical and syntactic pattern.

5) Mechanic refers to the use of the graphic convention of language.

To be clearly, the researcher will explain each point one by one. The first point, the term unity can be identified by seeing the topic sentence. The topic is a series of sentences about one idea in the text. The topic sentence contains words that need to be explained, described and supported in the sentences that follow in the paragraph. The second is the term coherence relates to the ideas or though sticks together so that the thought flow run smoothly within the text. The next point is the third point, in this point the students must have 
vocabulary refers to the words choice or diction in order to convey the ideas to the readers. The fourth point, language use is identified from the construction of well-formed sentences. The last point, is mechanic refers to spelling, punctuation, and capitalization.

Many people like writing narrative text in which they relate an experience that they had. Narrative text is enabling the writer to tell a story or incident. Every time someone tells another person about something that happened or occurred, she or he is telling a narrative or story. (Daniel Kies, 1969: 45-49), he states that narrative essay is told form a defined point of view, often the author's, and so there is feeling as well as specific and often sensory. The verbs are vivid and precise. The narrative essay makes a point is often defined in the opening sentences, but can also be found as the last sentence in the opening paragraph. It can be concluded that narrative is a story telling which has correlation with an events or sequence of events, or narrative is a sequence of events leading to climax. It can be inferred that climax is important part of narrative.

One of the many reasons why narrative has emerged since the 1980s as a seemingly ubiquitous mode across the human and social sciences can be seen to relate to the "tectonic shifts in our cultural architecture of knowledge following the crisis of the modernist episteme" (Brockmeier and Harre 2001, 39)in Matti et.al. (eds.) 2006

The conventions of story telling : plot, character, setting, climax and ending. It is usually filled with details' that are carefully selected to explain, support, or embellish the story. All of the details relate to the main point the writer is attempting to make.

From Setiyadi: (2007:7.21), said that narration maybe written from a sequence of pictures and students write the story they tell. It may also require students to write in full sentences from their activities, which they perform during the day, from the time they get up the time they go to bed.

Narrative, Text and Discourse introduces students to a range of ways in which narrative theory and analysis is used 'in real-world research practice'. The course provides both an overview and 'hands on' practice of using (both in the classroom and in the assessment) different varieties of narrative analysis. It is organized as series of postgraduate level participatory seminars/work shops in which students will learn about and gain experience of using a number of analytical approaches, with course lecturers drawing on their own methodological and substantive interests and research practices during the sessions.

The purpose of narrative report is to describe something. Many students write narrative reports thinking that these are college essay or papers. A narrative reports leaves a side of a discussion that put the events of the text into the context of what the text is about. The essential purpose of narrative is to tell story, but the detailed purpose may vary according to genre.

A narrative text will consists of the following structure:

1. Orientation: sets the scene and introduction the participants.

This element contains character of the story, place and time.

2. Complication: Describing the rising crises which the participants have to do with. This element contain full of event from introduction, problem, until climax. 
3. Resolution: Showing the way of participant to solve the crises, better or worse. This element is a solution from the conflict.

\section{Coda}

Closing part, it contain moral message, get from the problem.

By writing the students have more freedom to express ideas in a written form, their knowledge, imagination, feeling in the text or paragraph a poetry, text whether fiction and non-fiction. Setiyadi : (2007:7.30).

Writing not only involves the skill of using the target language in the written form but also the knowledge and the ability of using grammar and meanings of word.

\subsubsection{Language Features of Narrative}

a. Focus on specific and usually individualized participants.

b. Using the material processes (and in this text, behavior and Verbal processes)

c. Using relation processes and metal processes

d. Using temporal conjunctions and temporal circumstance.

e. Using Simple Past Tense

Hypothesis is temporary answer for research object which the truth must be tested empirically. Hypothesis states a kind of relationship on what we are looking for or studying, so hypothesis can be a statement temporarily as the truth as in reality. The hypotheses from this proposal are:

\subsubsection{The students get the difficulties to differentiate in genre}

2.4.2 The students less in vocabulary mastery, diction, discourse and still wrong in using tense or grammar.

\section{RESEARCH METHODOLOGY}

Research Design used in this research is Test Design, the researcher do the test to analyze students' ability in developing narrative text. The researcher uses the test to do the research first. From this instrument, the researcher wants to know about the students' ability in writing narrative text. The process of this test is at the first the researcher asks the students to write a narrative text that consist of some parts based on the theme. The students do the task to make narrative text, and they make narrative text with theme "Traveling".

There are two main variables of research; they are independent variable and dependent variable. Variable which has ability than effect of research named Independent variable while variable function as the situation of effect named Dependent variable. The writer has determined variables of the research, are:

1. Independent variable is developing narrative text as $\mathrm{X}$ variable

2. Dependent variable is students' ability as $\mathrm{Y}$ variable 
The population of this research is the Third semester of English Education Study Program in Muhammadiyah University of Metro Academic Year 2014 / 2015. There are 240 students in this population.

The sample of the research is quota sample. There are 36 students in this research. To get the data, the researcher asked to the English lecturer as the first observer, and does the test to the students about narrative texts to complete the data.

According to Sukardi" Fungsional kegunaan instrumen penelitian ini adalah untuk memperoleh data yang diperlukan ketika penelitian sudah menginjak pada langkah pengumpulan informasi di lapangan".

In this research there are three instrument to complete the data, they are test in the first time, continue to the observation, and then the last is the documentation, with this instrument the researcher can analyze the students' writing ability in developing narrative text completely.

The researcher uses the test to do the research first. This instrument is to know the students' ability in writing narrative text.

Test is in the first the researcher asks the students to write a narrative text that consist of some parts based on the theme. And now the students do the task to make narrative text, and they make narrative text with theme "Traveling".In the second, the researcher uses checklist in her observation, to checks the students' writing ability in developing narrative text, the difficult part of narrative text to the students. In the observation, the researcher as the observer. The third instrument is documentation; the researcher uses this instrument to collect the data about the result of students' ability in developing narrative text based on the observation.

In this research, the researcher uses some data collecting technique, they are :

1) Test, the researcher asks the students to make a narrative text with the the me "Traveling".

2) Observation, the researcher observes the students' ability in developing narrative text.

3) Documentation, to complete the data the researcher uses the documentation.

And to the complete explanation, the researcher draws below:

\subsubsection{Test}

An assessment intended to measure the respondents' knowledge or other abilities. A test is an assessment often administered in paper on the computer, intended to measure the takes-takers' or respondents' (often the student) knowledge, skill, attitudes or classification in many other topic. The measurement is the goal of testing called a test score.

In this research, the first time the researcher asks to the students to write a narrative text with theme "Traveling", after that the researcher moves among the students to control their activities, if they have finished, they must submit it, and then the researcher corrects the result of their task to developing narrative text. After that the researcher return their task, if there are the students get the low score, they must revise their text to be better than before, and the other students who get the higher score, help them to do it, and submit it again. It will be continued until they get the high score same with the other friend. 


\subsubsection{Observation}

Observation is either an activity of a living being (such as a human), consisting of receiving knowledge of the outside world through the senses, or the recording of data using scientific instruments.

The researcher does the observation of Muhammadiyah University of Metro because many problems what get in this University and the observation have been conducted for two meetings in this research. The first meeting for general observation like: ask how about students' writing ability in developing narrative text in this University? And the second meeting for gathering information it is about the caused of students' difficulty in writing narrative text and their development in writing narrative text.

\subsubsection{Documentation}

"Dokumentasi adalah catatan tertulis tentang berbagai kegiatan, peristiwa pada masa lalu" (W. Gulo. 123)

The meaning about appropriate with Arikunto' statement that "Dokumentasi adalah mencari data atau hal-hal yang berkaitan dengan masalah variabel yang berupa catatan, transkrip, buku, surat kabar, majalah, notulen rapat, dan buku legger".

Based on their statements, so the researcher can be concluding that the documentation is a way to collect the data is needed by a note. The document in this research is needed to complete the data such as collecting the data about the result of students' ability in developing narrative text based on the observation.

Data Analysis is the process of organizing the data in order to gain regularly of the pattern and form the research. The term interpretation can be defined as a procedure of giving meaning in the result of the analytic process.

The researcher uses qualitative descriptive method in this research, according to Leedy (1974: 79) that qualitative descriptive research in which the researcher imply looks at the tendency now and describes precisely what the researcher will investigate. This research is analyzing students' writing ability in developing narrative text. The researcher used test, observation, and all supporting documents from the English lecturer of the third semester in English education study program (see the appendices).

Based on Leedy's statement, the researcher chooses this method, because with qualitative descriptive method makes the researcher more clear to analyze and describes all of the problems happened in students' writing ability.

The researcher does the data analysis from to analyze the students' writing ability in developing narrative text. In the narrative text there are some parts, usually the students are confused to differentiate and to understand some part. In the title part, they must have the title connect with the theme. In the orientation, the students must give the problem background, and explain it. In the description of theproblematic events, in this part they must describe the problem will be appeared clearly. Next part in the resolution, they must write down the problem solving from the conflict. And the last is coda; from the text they must write the moral message of it. 


\subsubsection{Validity of The Data}

The researcher used triangulation in order to make the data to be more valid. Triangulation is a manner of collecting the data by combining two or more method in order to enrich the data and to have accurate conclusion ( Setiyadi, 1994). The data are considered to be field notes this term refers to all the data collecting including field note, the test result, observation sheet, official documents, and other material. In this research the writer use type triangulation. In methodology triangulation, we used the some method namely test, observation, and than documentation on order to get the data.

\subsubsection{Reliability of The Data}

A. Reliability of The Text

The researcher looks for the reliability from The Alpha Formula, because in this research the test has the interval score not only $0-1$, but also has interval $0-100$. The Alpha Formula :

$$
\begin{aligned}
& r_{11}=\left(\frac{k}{k-1}\right) \times\left(\frac{1-\sum \sigma_{b}^{2}}{\sigma_{1}^{2}}\right) \\
& \mathrm{r}_{11} \quad=\text { reliability of instrument } \\
& \mathrm{k} \quad=\text { the sum of question } \\
& \sum \sigma_{b}^{2}=\text { the sum of variants } \\
& \sigma_{b}^{2} \quad=\text { total of variants }
\end{aligned}
$$

And to get the total of variants the writer used:

$$
\begin{aligned}
& \sigma^{2}=\frac{\sum x^{2}-\left(\frac{\sum x^{2}}{n}\right)}{n} \\
& \sigma^{2} \quad=\text { total of variants } \\
& \sum x^{2}=\text { total of quadrate data } \\
& \mathrm{n} \quad=\text { the sum of data }
\end{aligned}
$$

B. Reliability of the Observation

To know the reliability of the observation that used in this research, the researcher used Crude Index Agreement, the formula can be drawn ;

$$
\begin{aligned}
& \text { CIA }=\frac{n}{N} \\
& \text { CIA }=\text { Crude Index Agreement }
\end{aligned}
$$


$\mathrm{n} \quad=$ the sum of the same code

$\mathrm{N} \quad=$ the sum of the object that observed

There are four steps here. The first step, to format from the researcher write parallel make a table, the second, enter the data inti the table, the third, to calculate the some code between them, the last step or the fifth step, enter the data into the Crude Index Agreement formula. From the result, we will know the grade of the reliability of this instrument.

The interpretation coefficient contingence standard by Suharsimi Arikunto( 2010,P.67) can be drawn :

$\begin{array}{llll}\text { Between } & 0,800 & -1,00 & \text { very high } \\ \text { Between } & 0,600 & -0,800 & \text { high } \\ \text { Between } & 0,400 & -0,600 & \text { medium } \\ \text { Between } & 0,200 & -0,400 & \text { low } \\ \text { Between } & 0,00 & -0,200 & \text { very low }\end{array}$

In the data analysis, the researcher evaluated the data based on the five aspect will be score in writing narrative text, such as:

1. Content refers to the substance of writing, the experience of the main idea (unity).

2. Organization refers to the logical organization of the content (coherence).

3. Vocabulary refers to the selection of the words those are suitable with content.

4. Language use refers to the use of the correct grammatical and syntactic pattern.

5. Mechanic refers to the use of the graphic convention of language.

The percentage of scoring from the writing components is derived as follow :

$\begin{array}{lll}\text { 1. Content } & : 30 \% \\ \text { 2. Organization } & : 24 \% \\ \text { 3. Vocabulary } & : 20 \% \\ \text { 4. Language Use } & : 25 \% \\ \text { 5. Mechanics } & : 5 \%\end{array}$

Below is the classification of scoring criteria adopted from H. L. Jacob et al (1981 : 90)

\section{Content}

30-27 EXCELLENT TO VERY GOOD: knowledge able substantive, development of thesis or topic relevant to assign topic.

26-22 GOOD TO AVERAGE: some knowledge of subject, adequate range, limited development thesis, mostly relevant to topic but lack detail.

22-17 FAIR TO POOR: limited knowledge of subject, little substances, inadequate development of the topic.

16-13 VERY POOR: doesn't shoe knowled ge, not pertinent, or not enough to evaluate.

\section{Organization}

20-18 EXCELLENT TO VERY GOOD: fluent expression, ideas clearly stated / support, well organized, logical sequencing, cohesive. 
17-14 GOOD TO AVERAGE: somewhat copy, loosely organized, but main idea stand out, limited support, logical but incomplete sequencing.

13-10 FAIR TO POOR: not fluent, ideas confused or disconnect, lacks logical, sequencing and development.

9-7 VERY POOR: doesn't to communicate, no organization or not enough to evaluate.

\section{Vocabulary}

20-18 EXCELLENT TO VERY GOOD: sophisticated range, effective word or idiom choice and usage word from mastery, appropriate register.

17-14 GOOD TO AVERAGE: adequate range, occasional error of word or idiom choice and usage, meaning confused or obscured.

13-10 FAIR TO POOR: limited range, frequent error of word or idiom choice and usage, meaning confused or obscured. 9-7

VERY POOR: essentially translation, little knowledge of vocabulary, idioms, word form or not enough to evaluate.

\section{Language Uses}

25-23 EXCELLENT TO VERY GOOD: effective complex construction, few errors of agreement, tense number, word order/function, articles, pronoun, preposition.

21-18 GOOD TO AVERAGE: effective but simple construction, minor problem in a simple construction, several errors of agreement, tense number, word order/function, articles, pronoun, preposition but meaning seldom obscure.

17-11 FAIR TO POOR: major problem in complex/ simple construction, frequent error of negation, agreement, tense number, word order/function, articles, pronoun, preposition, and/ or fragments, run-ons, de letions, meaning confused, or obscured.

10-5 VERY POOR: virtually not mastery of sentences construction rules, domination by errors, does not communicate, or not enough to evaluate.

\section{Mechanics}

EXCELLENT TO VERY GOOD: demonstrated mastery of conventions, few errors spelling, punctuation, capitalization, paragraphing.

GOOD TO AVERAGE: occasional errors of spelling, punctuation, capitalization, paragraphing, but meaning not obscured. poor hand writing, meaning confused or obscured

VERY POOR: no mastery of conventions, dominated by errors of spelling, punctuation, capitalization, paragraphing, hand writing illegible, or not enough to evaluate. 
Based on the classification of scoring criteria by H. L. Jacob et.al., the researcher can be conclude that in analytic, different components or features of the students' responses are given separate scores. The scoring categories included in an analytic system should reflect instructional objectives and plan. Determining levels of performance from each category generally reflect teachers' expectations, based on past experience, of previous students' performance. Analytic scoring provided useful feedback to students and diagnostic information to teacher about specific areas of performance that are satisfactory or unsatisfactory.

\section{RESEARCH FINDING AND ANALYSIS}

As mentioned in chapter I, the researcher conducted to analyze Students' Ability in Developing Narrative Text of the third semester of English Education Study Program of Teacher Training and Education Faculty in Muhammadiyah University of Metro. In order to analyze students' ability in developing narrative text, the researcher used writing test, observation, and interview as the instruments in this research. The first is, test to get the data about the students' ability in developing narrative text. The second is observation to observe the students' ability in developing narrative text and then the third is interview to support the data and to analyze students' ability as well as the cause of students' difficulty in deve loping narrative text.

The researcher carried out in the third semester of English Education Study Program of Teacher Training and Education Faculty in Muhammadiyah University of Metro. It consists of 166 students but the researcher takes 33 students as the sample of this research.

\subsubsection{Triangulation of the Instrument}

In this research, the researcher measured validity of the instrument used triangulation. The method was used to combine three instruments; they are test, observation and interview. Test was used as primary technique in order to make the data more valid in scoring students' ability in developing narrative text. The researcher used impression method to score the students narrative writing. The researcher asked two persons who has competency in English to give score students' narrative writing (Heaton, 1991: 148). So the researcher gave the students' writing to differentiate markers to be score. The results of the two inters marker were added and devided by two to get the average score for each students. For example, if marker 1 gave total score 65, marker 2 gave total score 75, and then the final score was 70 . So, it shows that score reliable, because the researcher gave the students' writing with different paper and at the same time. The researcher not only did the research by using the test but also the reseacher used observation in order to know the students' ability in developing narrative text. Beside that, to support the data and analyze students' ability in developing narrative text, the researcher used interview in this research.

\subsubsection{The Reliability of the Test}

The writing test used in this research consists of 5 items. This test was used to measure the student ability in developing narrative text. In order to find out whether the writing test was suitable to be used in real research, the researcher did the test to the 10 students of the fifth semester of English Education Study Program in Muhammadiyah University of Metro. The result of the test was found that the reliability of writing test was 0,9075 .

In this research, the researcher uses the alpha formulation to know the reability of the text

The Alpha Formula : 
$r_{11}=\left(\frac{k}{k-1}\right) \times\left(\frac{1-\sum \sigma_{b}^{2}}{\sigma_{1}^{2}}\right)$

$\mathrm{r}_{11} \quad=$ reliability of instrument

$\mathrm{k}=$ the sum of question

$\sum \sigma_{b}^{2}=$ the sum of variants

$\sigma_{b}^{2} \quad=$ total of variants

The total variants the writer used formu lation below:

$\sigma^{2}=\frac{\sum x^{2}-\left(\frac{\sum x^{2}}{n}\right)}{n}$

$\sigma^{2}=$ total of variants

$\sigma_{1}^{2}=\frac{3221-\frac{175^{2}}{10}}{10}=\frac{3221-3062,5}{10}=15,85$

$\sigma_{2}^{2}=\frac{2329-\frac{149^{2}}{10}}{10}=\frac{3221-2220,1}{10}=10,89 \sigma_{3}^{2}=\frac{2513-\frac{157^{2}}{10}}{10}=\frac{2513-2464,9}{10}=4,81$

$\sigma^{2}{ }_{4}=\frac{4007-\frac{183^{2}}{10}}{10}=\frac{4007-3348,9}{10}=65,81 \sigma^{2}{ }_{5}=\frac{79-\frac{27^{2}}{10}}{10}=\frac{79-72,9}{10}=0,61$

$\sum \sigma_{b}^{2}=15,85+10,89+4,81+65,81+0,61=97,97$

The Total of Variants

$\sigma^{2}=\frac{\sum x^{2}-\left(\frac{\sum x^{2}}{n}\right)}{n}$ 


$$
\sigma^{2}=\frac{51323-\frac{691^{2}}{10}}{10}=\frac{51323-47748,1}{10}=357,49
$$

Enter to the Alpha formu lation

$$
\begin{aligned}
& r_{11}=\left(\frac{k}{k-1}\right) \times\left(\frac{1-\sum \sigma_{b}^{2}}{\sigma_{1}^{2}}\right) \\
& r_{11}=\left(\frac{5}{5-1}\right) \times\left(\frac{1-97,97}{357,49}\right)=\left(\frac{5}{4}\right) x(1-0,2740) \\
& =\left(\frac{5}{4}\right) x(0,726) \\
& =1,25 x 0,726=0,9075
\end{aligned}
$$

Referring to the calculation above got $\mathrm{r}_{11}=0,9075$, so reability of the test have very high criteria. It means that the test can be used as an instrument.

From the calculation above, it was found that the writing test was suitable to be used in the real sample because the reliability is very high.

\subsubsection{The reliability of The Observation}

The observation used in this research consists of 10 items. Those observation items measured the students' ability developing narrative text. in this research the researcher used Crude Index Agreement (CIA). The data showed that the reliability efficient of the observation is 0,6 (see appendix 13) it means that the observation had high reliability.

It indicates that observation used in this research reliable application instrument to measure student ability in developing narrative text.

\subsubsection{The Data from Interview}

The students are informant in this research. The result of the interview would be explain bellow. The researcher give some questions to the students with face to face. There were 15 questions in the interview. In process of doing the interview, the researcher calls the students' name with one by one. After that, the researcher give 15 questions to the students and the students answer it. After fin ishing all items, the researcher checked the answers of each item. To open-ended interview form, the researcher interpreted the item and then took conclusion. 


\subsubsection{The Data from Students' Responses}

Item 1: this item is concerned with response student toward English lesson. The data shows that 21 students said that they like English lesson. 8 students said that they like English lesson very much. And 4 students not so like English lesson.

Item 2: this item is about whether students' response toward teaching writing. 18 students said that they like teaching writing. 5 students said that they like teaching writing very much. And 10 students not so like teaching writing.

Item 3: This item is about how to English use in the class. 24 students said that their lecturee apply English was the best. 6 students said that their lecturer apply English was good. And 3 students said that their lecturer is less applying English use.

Item 4: This item is about how to students' improvement understanding in narrative text. The data shows that 16 students said that their improvement understanding in narrative text is the best. 12 students said that their improvement in narrative text is good. And 5 students said that their improvement in narrative text is less.

Item 5: This item is about student's opinion toward lecturer's method in learning narrative text. The data shows that 25 students said that lecturer's method in learning narrative text is the best. 5 students said that lecturer's method in learning narrative text is good. And 3 students said that lecturer's method in learning narrative text is less good.

Item 6: This item is concerned with response's students in studying narrative text. The data shows that 18 students said that studying narrative text was very easy to understand. 8 students said that studying narrative text was easy to understand. And 7 students said that studying narrative text was difficult to understand.

Item 7: This item is about how far the students like studying narrative text. The data shoes that 15 students saind that they very like studying narrative text. 7 students said that they like studying narrative text. And 11 students said that they not so like studying narrative text.

Item 8: This item is concerned with students' response how to identify part of narrative text. The data shows that 8 students said that to identify part of narrative text is very easy. 11 students said that to identify part of narrative text is easy. And 14 students said that to identify part of narrative text is difficult.

Item 9: This item is concerned with students' opinion whether studying the narrative text is easy or not. The data shows that 16 students said that studying narrative text is easiest. 8 students said that studying narrative text is easy. And 9 students said that studying narrative text is difficult.

Item 10: This item is about how to students's way to express their ideas in writing narrative text. The data shows that 14 students said that it is easiest to express idea in writing narrative text. 8 students said that it is easy to express idea in writing narrative text. And 11 students said that it is difficult to express idea in writing narrative text.

Item 11: This item is about how far the students to choose good words in narrative text. The data shows that 8 students said that it is easiest to choose good words in narrative text. 10 
students said that it is easy to choose good words in narrative text. And 15 students said that it is difficult to choose good words in narrative text.

Item 12: This item is about how far the lecturer's way in teaching narrative text. 25 studets said that lecturer's way in teaching narrative text is the best. 5 students said that lecturer's way in teaching narrative text is good. And 3 students said that lecturer's way in teaching narrative text is less good.

Item 13: This item is the result of students' narrative writing. 11 students said that they got the best result in narrative writing. 17 students said that they got a good result in narrative wriitng. And 5 students said that they got less score in narrative text.

Item 14: This item is whether students reviewing narrative text at home. 8 students said that they like reviewing narrative text very much. 7 students said that they like reviewing narrative text at home. And 18 students said that they do not so like reviewing narrative text at home.

Item 15: This item is concerned with students' opinion toward lecturer's character in teaching narrative text. The data shows that 24 students said that their lecturer's character in class is the best toward to the students; he always took care of the students. 5 students said that the lecturer's character in teching narrative text in class is good. And 4 students said that the lecturer's character was not so kind in teching narrative text.

Table 4.1 The Data of Students' Response in Interview

\begin{tabular}{|c|c|c|}
\hline NO & Questions & Sum of Students' Response \\
\hline 1. & Do you like English lesson? & $\begin{array}{l}\text { a. } 8 \text { students : verylike } \\
\text { b. } 21 \text { students : like } \\
\text { c. } 4 \text { students : not so like }\end{array}$ \\
\hline 2. & Do you like s tudy of writing? & $\begin{array}{l}\text { a. } 5 \text { students : ve ry like } \\
\text { b. } 18 \text { students : like } \\
\text { c. } 10 \text { students : not so like }\end{array}$ \\
\hline 3. & $\begin{array}{l}\text { How can be apply your English lecturer when } \\
\text { he teaches in the dass? }\end{array}$ & $\begin{array}{l}\text { a. } 24 \text { students : the best } \\
\text { b. } 6 \text { students : good } \\
\text { c. } 3 \text { students : less }\end{array}$ \\
\hline 4. & $\begin{array}{l}\text { How can you increas your ability in making } \\
\text { narrative text? }\end{array}$ & $\begin{array}{l}\text { a. } 16 \text { students : the best } \\
\text { b. } 12 \text { students : good } \\
\text { c. } 5 \text { students : less }\end{array}$ \\
\hline 5. & $\begin{array}{l}\text { How are the methods that your lecturer use in } \\
\text { lea ming na rra tive text? }\end{array}$ & $\begin{array}{l}\text { a. } 25 \text { students : the best } \\
\text { b. } 5 \text { students : good } \\
\text { c. } 3 \text { students : less }\end{array}$ \\
\hline 6. & How farcan you understand of narra tive text? & $\begin{array}{l}\text { a. } 18 \text { students : the easiest } \\
\text { b. } 8 \text { students : easy } \\
\text { c. } 7 \text { students : difficult }\end{array}$ \\
\hline 7. & How far do you like study of na rra tive text? & $\begin{array}{l}\text { a. } 15 \text { students : ve ry like } \\
\text { b. } 7 \text { students : like } \\
\text { c. } 11 \text { students : not so like }\end{array}$ \\
\hline 8. & $\begin{array}{l}\text { How far can you understand part of na rrative } \\
\text { text? }\end{array}$ & $\begin{array}{l}\text { a. } 8 \text { students : the easiest } \\
\text { b. } 11 \text { students : easy } \\
\text { c. } 14 \text { students : difficult }\end{array}$ \\
\hline 9. & Do you think that na rrtive text is easy for you? & $\begin{array}{ll}\text { a. } & 16 \text { students : the easiest } \\
\text { b. } & 8 \text { students : easy } \\
\text { c. } & 9 \text { students : difficult }\end{array}$ \\
\hline 10. & $\begin{array}{l}\text { How can you express your idea in writing } \\
\text { narrative text? }\end{array}$ & $\begin{array}{ll}\text { a. } & 14 \text { students : the easiest } \\
\text { b. } & 8 \text { students : easy } \\
\text { c. } & 11 \text { students }: \text { difficult }\end{array}$ \\
\hline 11. & How far can you choose words that use in & a. 8 students : the easiest \\
\hline
\end{tabular}




\begin{tabular}{|c|c|c|}
\hline & narrative text? & $\begin{array}{ll}\text { b. } 10 \text { s tudents : easy } \\
\text { c. } 15 \text { students : difficult }\end{array}$ \\
\hline 12. & $\begin{array}{l}\text { How far your lecturer's way when he teaches } \\
\text { narrative text? }\end{array}$ & $\begin{array}{l}\text { a. } 25 \text { students : the best } \\
\text { b. } 15 \text { students : good } \\
\text { c. } 3 \text { students : less }\end{array}$ \\
\hline 13. & $\begin{array}{l}\text { What is the score that you get when you study } \\
\text { of narrative text? }\end{array}$ & $\begin{array}{l}\text { a. } 11 \text { students : the best } \\
\text { b. } 17 \text { students : good } \\
\text { c. } 5 \text { students : less }\end{array}$ \\
\hline 14. & $\begin{array}{l}\text { Do you always study of narrative text in your } \\
\text { home? }\end{array}$ & $\begin{array}{l}\text { a. } 8 \text { students : verylike } \\
\text { b. } 7 \text { students : like } \\
\text { c. } 18 \text { students : not so like }\end{array}$ \\
\hline 15. & $\begin{array}{l}\text { How is your lecturer's character when he } \\
\text { teaches narrative text? }\end{array}$ & $\begin{array}{l}\text { a. } 24 \text { students : the best } \\
\text { b. } 5 \text { students : good } \\
\text { c. } 4 \text { students : less }\end{array}$ \\
\hline
\end{tabular}

\subsubsection{The Result of The Students' Writing Test}

In this test, the writer asks the students to make narrative text with theme "Friendship" with the scoring classification by H.L.Jocob et.al. In the process. Based on the writing test, the reseacher gets the data below

Table. 4.2 Students' Writing Score

\begin{tabular}{|l|c|c|c|c|}
\hline No & $\begin{array}{c}\text { Score } \\
\text { Interval }\end{array}$ & Frequency & $\begin{array}{c}\text { Percentage } \\
\%\end{array}$ & $\begin{array}{c}\text { Alphabetical } \\
\text { Score }\end{array}$ \\
\hline 1 & $8,0-10$ & 1 & $3 \%$ & A \\
\hline 2 & $7,6-7,9$ & 2 & $6 \%$ & A- \\
\hline 3 & $7,1-7,5$ & 12 & $37 \%$ & B+ \\
\hline 4 & 7,0 & 2 & $6 \%$ & B \\
\hline 5 & $6,5-6,9$ & 7 & $21 \%$ & B- \\
\hline 6 & $6,1-6,4$ & 4 & $12 \%$ & C+ \\
\hline 7 & 6,0 & 1 & $3 \%$ & C \\
\hline 8 & $5,5-5,9$ & 4 & $12 \%$ & C- \\
\hline 9 & $5,0-5,4$ & 0 & $0 \%$ & D \\
\hline 10 & $<5$ & 0 & $0 \%$ & E \\
\hline
\end{tabular}

Source: Test of Narrative Text at the Third Semester of English Education Study Program in Muhammadiyah University of Metro on December $20^{\text {th }} 2015$

The data in table 4.2 can be interpreted as follows:

a. 1 student ( $3 \%)$ score $8,0-10$

b. 2 students $(6 \%)$ get the score $7,6-7,9$

c. 12 students $(37 \%)$ get score $7,1-7,5$

d. 2 students $(6 \%)$ get score 7,0

e. 7 students $(21 \%)$ get score $6,5-6,9$

f. 4 students $(12 \%)$ get score $6,1-6,4$

g. 1 student $(3 \%)$ get score 6,0

h. 4 students $(12 \%)$ get score $5,5-5,9$

i. $\quad 0$ student $(0 \%)$ get score $5,0-5,4$

j. $\quad 0$ student $(0 \%)$ get score $<5$ 
From the data above, the reseracher can be conclude that the students still difficulty in developing narrative text, because the students who get the score up to 8,0 - 10 just 1 people and 2 people got 7,6 - 7,9 score, 7,1-7,5 were 12 people, 7,0 just 2 people, $6,5-6,9$ were 7 people, 6,1 - 6,4 were 4 people, 6,0 just 1 people, 5,5-5,9 were 4 people and there is not student got 5,0-5,4. It means that more students got the higer score then lower score.

Table. 4.3 Students' score in Each Component of writing test.

\begin{tabular}{|c|c|c|c|c|c|}
\hline Criteria & $\begin{array}{c}\text { Content } \\
(\%)\end{array}$ & $\begin{array}{c}\text { Organization } \\
(\%)\end{array}$ & $\begin{array}{c}\text { Vocabulary } \\
(\%)\end{array}$ & $\begin{array}{c}\text { Lang. uses } \\
(\%)\end{array}$ & $\begin{array}{c}\text { Mechanic } \\
(\%)\end{array}$ \\
\hline $\begin{array}{c}\text { Excellent to very good } \\
\text { Good to average }\end{array}$ & $(0 \%)$ & $3(9 \%)$ & $1(3 \%)$ & $(0 \%)$ & $(0 \%)$ \\
Fair to poor & $4(12 \%)$ & $20(60 \%)$ & $23(69 \%)$ & $14(42 \%)$ & $(0 \%)$ \\
Very poor & $28(84 \%)$ & $10(30 \%)$ & $9(27 \%)$ & $19(57 \%)$ & $18(54 \%)$ \\
& $1(3 \%)$ & $(0 \%)$ & $(0 \%)$ & $(0 \%)$ & $15(45 \%)$ \\
\hline
\end{tabular}

Source: The Average Score of Marker in Each Component of Writing

\subsubsection{The Students' Difficulty in Each Component of Writing}

The description of the students' difficulty in each component of writing can be seen as follow:

\section{a. The Score of The Content Components}

a. There is no student get the excellent to very good in developing narrative text

b. There are 4 students (12\%) score $26-22$, because the students have some knowledge of subject, adequate range, mostly relevant to topic but lack detail.

c. There are 28 students $(84 \%)$ score $22-17$, because the students have limited knowledge of subject, little substances, inadequate development of the topic in writing.

d. There is 1 student (3\%) score 16 - 13, because the student didn't showed knowledge, not pertinent, or not enough to evaluate.

b. The score of Organization Component

a. There are 3 students $(9 \%)$ score $20-18$, because the students havefluent expression, ideas clearly statedsupport, well organized, logicalsequencing, cohesive.

b. There are 20 students $(60 \%)$ score $17-14$, because the students have somewhat copy, loosely organized, but main idea stand out, limited support, logical but incomplete sequencing.

c. There are 10 students $(30 \%)$ score $13-10$, because the students notfluent, ideas confused or disconnect, lacks logical, sequencing andde velopment.

d. There is no student get score $9-7$.

\subsubsection{The score of Vocabulary Component}

a. There is 1 student (3\%) score $20-18$, because the students usedsophisticated range, effective word or idiom choice and usage wordfrom mastery, appropriate register. 
b. There are 23 students $(69 \%)$ score $17-14$, because the students usedadequate range, occasional error of word or idiom choice and usage, meaning confused or obscured.

c. There are 9 students (27\%) score 13 - 10, because the students havelimited range, frequent error of word or idiom choice and usage, meaning confused or obscured.

d. There is no student get score $9-7$.

\subsubsection{The Score of Language Use Component}

a. There is no student get score $25-23$.

b. There are 14 students (42\%) score $21-18$, because the students haveeffective but simple construction, several errors of agreement, tense number, word order / function, articles, pronoun, preposition but meaning seldom obsecure.

c. There are 19 students $(57 \%)$ score 17 - 11, because the students havemajor problem in complex / simple construction, frequent error ofnegation, agreement, tense number, word order / function, articles,pronoun, preposition, and / fragment, runons, deletions, meaningconfused or obsecured.

d. There is no student get score 10-5.

\subsubsection{The Score of The Mechanic Component}

a. There is no student get score 5 and 4 .

b. There are 18 students (54\%) score 3, because the students have frequent errors of spelling, punctuation, capitalization, paragraphing poor handwriting, meaning confused or obscured

c. There are 15 students $(45 \%)$ score 2 , because the students no mastery ofconventions, dominated by errors of spelling, punctuation,capitalization, paragraphing, hand writing illegible, or not enough toevaluate.

\subsubsection{The Result of Students' Observation Sheet}

The Observation sheet had five criteria of the students' ability in developing narrative text, and in this observation the reseacher used two observers.

Table.4 Observation Sheet of Students' ability in Developing Narrative Text

\begin{tabular}{|c|l|c|c|c|c|c|c|}
\hline \multirow{2}{*}{ No } & \multicolumn{1}{|c|}{$\begin{array}{c}\text { Students } \\
\text { Activity }\end{array}$} & \multicolumn{3}{|c|}{ Observer I } & \multicolumn{3}{|c|}{ Observer II } \\
\cline { 3 - 8 } & $\mathbf{1}$ & $\mathbf{2}$ & $\mathbf{3}$ & $\mathbf{1}$ & $\mathbf{2}$ & $\mathbf{3}$ \\
\hline 1 & $\begin{array}{l}\text { Writing the title } \\
\text { of the text }\end{array}$ & 5 & 10 & 18 & 6 & 11 & 16 \\
\hline 2 & $\begin{array}{l}\text { Make } \\
\text { Orientation part } \\
\text { of the text }\end{array}$ & 17 & 12 & 4 & 17 & 11 & 5 \\
\hline 3 & $\begin{array}{l}\text { Make } \\
\text { Description of } \\
\text { the problematic } \\
\text { events part of } \\
\text { the text }\end{array}$ & 6 & 11 & 16 & 5 & 10 & 18 \\
\hline 4 & $\begin{array}{l}\text { Make Resolution } \\
\text { part of the text }\end{array}$ & 7 & 10 & 15 & 7 & 10 & 15 \\
\hline 5 & Make Coda part & 18 & 8 & 7 & 18 & 9 & 6 \\
\hline
\end{tabular}




\begin{tabular}{|c|l|l|l|l|l|l|l|} 
& of the text & & & & & & \\
\hline 6 & $\begin{array}{l}\text { Contents refers } \\
\text { to the substance } \\
\text { of writing }\end{array}$ & 12 & 17 & 4 & 11 & 17 & 4 \\
\hline 7 & $\begin{array}{l}\text { Organization } \\
\text { refers to the } \\
\text { logical } \\
\text { organization of } \\
\text { the text }\end{array}$ & 13 & 15 & 5 & 12 & 16 & 5 \\
\hline 8 & $\begin{array}{l}\text { Vocabulary } \\
\text { refers to the } \\
\text { selection of the } \\
\text { words }\end{array}$ & 5 & 10 & 18 & 6 & 11 & 16 \\
\hline 9 & $\begin{array}{l}\text { Language use } \\
\text { refers to the use } \\
\text { of the correct } \\
\text { grammatical and } \\
\text { syntactical } \\
\text { pattern }\end{array}$ & 7 & 10 & 15 & 7 & 10 & 15 \\
\hline 10 & $\begin{array}{l}\text { Mechanics refers } \\
\text { to the use of the } \\
\text { graphic } \\
\text { convention of } \\
\text { language }\end{array}$ & 11 & 17 & 4 & 12 & 16 & 5 \\
\hline
\end{tabular}

Note :

1. I : Imperfect

2. SU : Sufficient

3. $\mathrm{P}$ : Perfect

4.

\subsubsection{The First Observer}

Based on the data, the first observer observes that:

a. There are five imperfect aspects, the first, in making coda part of narrative text: the students cannot make a moral message of the text. The second in their vocabulary: the students have not selected the word well, and students' vocabulary mastery is low.

b. There are ten sufficient aspects, the first in making a resolution part in narrative text: because the writer found that a lot of the students' resolution part was some with the other students. The second in organization part, and then the third in language use: in this part many students wrong in grammatical especially the tense.

c. There are eighteen perfect aspects are, writing the title of the text: they have a good diction to make a title of the story. Make description of the problematic event, the students have arrived the problem was happened: And then the last mechanic, the students used punctuation well in wrote a text.

\subsubsection{The Second Observer}

And than, the second observer, observed that;

a. There are six imperfect aspects, are making coda and vocabulary use, same with the first observer.

b. There are eleven sufficient aspects, the first in making a resolution part in narrative text: because the writer found that a lot of the students' resolution part was some with the other students. The second in organization part, and then the third in language use: in this part many students wrong in grammatical especially the tense. 
c. There are sixteen perfect aspects are, writing the title of the text: they have a good diction to make a title of the story. Make description of the problematic event, the students have arrived the problem was happened: And then the last mechanic, the students used punctuation well in wrote a text.

\subsection{Discussion}

\subsubsection{Discussion of Students' Responses}

Based on the interview given for the third semester of English Education Study Program of Teacher Training and Education Faculty in Muhammadiyah University of Metro. The interview was made as simple as possible to make the students able to answer easily. After knowing their problems and analysis the result of interview, below some points that could be concluded from the result of interview.

\subsubsection{Students' Responses Toward English Subject}

Eight students said that they like study English so much because 21 students said that they like English lesson. But 4 students said that they less like reviewed to study English at home.

\subsubsection{Students' Responses Toward Lecturer}

Here the reseacher asked about their lecturer's way and character in teaching writing. Honestly 5 students addmited their lecturer paid attention for teaching in the class and have a good attitude. Twenty four students said that their lecturer had the best applying English for teaching. And four students said that their lecturer was not so kind in applying English for teaching.

\subsubsection{Discussion of Students' ability in Developing Narrative Text}

Based on the data gained, it was found that the students' ability in developing narrative text was good enough, because after doing the test the writer can be concluded that many students were passing from the KKM, it would be clear by the table below:

Table.5 the Amount of the Students in KKM

\begin{tabular}{|c|c|c|}
\hline No & Score & Sum \\
& & \\
\hline 1. & $\geq 5,5$ & 0 \\
2. & $<5,5$ & \\
& & \\
\hline
\end{tabular}

Source: Result of Writing Narrative text in The Third Semester of English Education Study Program in Muhammadiyah University of Metro on December $20^{\text {th }} 2015$.

More of half of students could develop narrative text well. The reseacher asked the students wrote narrative text with theme" friendship" and from the theme, they could develop their idea, their image to make a text and to make some interesting story about the theme.

In writing narrative text the students are low in vocabulary use, and still wrong in grammatically especially in using past tense, but they are using present tense to write 
narrative text, that is wrong, they must use past tense to write narrative text, because the characteristic of narrative is using past tense.

Based on the observation sheet about students' ability in developing narrative text, the reseacher could conclude that the students had the difficulty in making coda part: a moral message of the story from the writer to the reader. And then resolution part: many of the students had the difficulty in making problem solving of the conflict arises. But they had a good orientation part, because they can mention the figure and the place of the story clearly, and they had a good content.

Based on the writing test and the observation above, the writer can answer the problem formulation, are:

1 The students less in vocabulary mastery grammatically still wrong, meaning confused or obscured and limited knowled ge of the subject.

2 The students get the difficulty to differently the part of narrative text, especially in coda and resolution. It can see that they can not make a moral message in the text to the reader and than resolution part: they have the difficulty to make the problem solving of the conflict in their story.

\section{CONCLUSION, IMPLICATION, AND SUGGESTIONS}

\subsection{CONCLUSSION}

Based on Research Objective and the analysis of the data from both test and observation, the writer sums up that:

5.1.1 The students in the third semester of English Education Study Program of Teacher Training and Education Faculty in Muhammadiyah University of Metro have a good ability in developing narrative text, because more of a half of the students has passed from the KKM. We can see from the result of writing test that there are 33 students or $100 \%$ have score up to 59 with detail such as, 1 student $(3 \%)$ gets the score between $8,0-10,2$ students $(6 \%)$ get the score between $7,6-7,9,12$ students $(37 \%)$ get score between $7,1-7,5,2$ students $(6 \%)$ get score 7,0, 7 students $(21 \%)$ get score between $6,5-6,9,4$ students $(12 \%)$ get score between $6,1-6,4,1$ student $(3 \%)$ get score $6,0,4$ students $(12 \%)$ get score between 5,5 - 5,9, and there is not student got lower score < 5,4 .

5.1.2 The students get unsatisfactory in making resolution part, so they cannot make problem solving from the conflict, and the other is organization of the text; the students still not fluent, no organization and the confusing ideas or disconnection. And then language uses: frequent error of negation, and tense or the grammatically is wrong.

5.1.3 The students get satisfactory in making orientation part, because they can mention the figure of the story, the place and time clearly, and their content of the text is good, the development of the theme relevant and have some knowledge of the subject.

5.1.1 The students are low in vocabulary mastery, the writer can be conclude it because, in doing the test, the students are still difficulty to translate from Indonesia into English, they have the difficulty to trans late phrase, statement and common vocabulary. 
5.1.2 The students have the difficulty to differentiate about the function of each part in narrative text, especially to make coda or moral message from the writer to the reader. And then resolution part; they cannot overcome the problem of the story emerging in the conflict, their story has not been related from one part to the other part previously.

5.1.3 The students in the third semester of English education study programare active students, because the students always ask to the reseacher about something that they do not understand before they do the test from the reseacher.

\subsection{SUGGESTION}

Based on Research Benefit and the conclusion above, the reseacher would like to suggest:

5.2.1 The students as the learners should have vocabulary mastery in order to get make a good narrative text with variety diction and their text had a good content with large knowledge, ideas were clearly stated, because we can improve our story if we have a good vocabulary mastery, but we will not write anymore if we do not have vocabulary mastery and if it happens so we can not give the information about our story to he reader.

5.2.2 The students are hoped want to study hard at home or take the course to improve their achievement in English because English is very important for their future, by doing the drill and self exercise continuously they can improve their knowled ge and mastery in English.

5.2.3 We think so writing is something difficult if, but it will be easy if we always doing it and drill our selves to write our idea in written form. If we have habit do it, so we will be easy to write something.

\section{REFERENCES}

Anderson, M., Anderson, K,. (1997). Text Types in English1 \& 2. MacmillanEducation.

Bhatia, Vijay K. (1993). Analyzing Genre: Language Use in Professional Settings.New York. Longman.

Dudeney, G., \&Hockly, N. (2007). How to Teach English with Technology. England. Longman.

Faisal. (2010). The Effectiveness of Internet-based Materials to Teach Writing Viewed from Students' Creativity, An Experimental Research in the Semester FourStudents of the EnglishDepartment, Teacher Training and Education Faculty,Muhammadiyah University ofPurwokerto, in the Academic Year of 2009/2010

Harris, J. (1993). Introducing Writing. England. Penguin Group.

Hernowo. (2003). Quantum Writing. Bandung. Mizan Learning Center.

Hikmah, Baiq (2011). Improving Students' Writing Skill Using Email, A Classroom Action Research in the Seventh Grade Students of SMP Negeri 2 Selong in the Academic Year of 2010/2011 
Hornby, AS. (2002). Oxford Advanced Learner's Dictionary. Oxford University Press; New York.

http://www.web.net/\%7Erobrien/papers/arfinal.html-_edn3 accessed:June 20, 2012

http://leostcloudstate.edu /acadwrite/ descriptive html accessed: June 20, 2012

http: //leostcloudstate. edu/acadwrite /descriptive.html accessed: June 20, 2012

Kasanga, L. A. (1996). Peer Interaction and Second

Language Learning. Canadian Modern Language Review, 52 (4), 611-639

Madsen, Harold, S. (1983). Technique in Testing. New York. Oxford University Press.

Maurer, M. M. \& Davidson, S. G. (1998). Leadership in Instructional Technology. NJ: Prentice Hall Inc.

M. Reid. Joy. (1994). The process of Paragraph Writing, Second Edition. Prentice Hall Regents. New Jersey

Nicholas, H. (1982). A History of Foreign Word in English. 48 Grovesnor Street. London.

Nisa Aulia Azam. (2011). Utilizing Students'Blog to Improve Writing Skill (An Action Research at $8^{\text {th }}$ Grade of SMP NegeriWonogiri in the Academic Year of 2010/2011). Surakarta.

Schampfer Azar, Betty. (1992). Fundamentals of English Grammar. Regents/ Prentice hail; New Jersey.

Qiubai, Qin. (2000). Genre Analysis and Its Implication for EFL Teaching. Lecture Notes of Summer School for Foreign Language Teacher in China, Hangzou. Zhejiang. 